8:40 TROUBLED WATERS: THE BIOLOGICAL INVASION OF SOUTHERN GALIFORNIA WATERWAYS.

Louanne McMartin. Non-native Invasive Species Program, U.S. Fish and Wildlife Service, Stockton Fish and Wildlife Office, Stockton, CA 95205. IN GALIFORNIA WITH DATA FROM THE UPPER OWENS RIVER WATERSHED. G.K. Noda. University of California, Los Angeles, Department of Ecology and Evolutionary Biology, Box 951606, 621 Charles E. Young Dr. South, Los Angeles, CA 90095.

9:20 MUDSNAILS INVADE THE 'BU: A GASE STUDY IN INSTITUTIONAL RESPONSES TO INVASIONS.

D. M. Tamanaha and J. R Topel. Santa Monica Bay Restoration Commission, 320 West $4^{\text {th }}$ St., Suite 200, Los Angeles, CA 90013.

9:40 DEVELOPMENT OF BIOLOGICAL CONTROL FOR THE NEW ZEALAND MUD SNAIL.

T. Dudley ${ }^{1}$, K.D. Lafferty ${ }^{2,1}$, B.L. Fredensborg ${ }^{1}$, and A.M. Kuris ${ }^{3,1}$. ${ }^{1}$ Marine Science Institute; ${ }^{3}$ Department of Ecology, Evolution, and Marine Biology; ${ }^{2}$ US Geological Survey, Western Ecological Research Center, ${ }^{1,2,3}$ University of California, Santa Barbara, CA 93106.

10:00 EFFECTS OF URBANIZATION ON THE DISTRIBUTION AND ABUNDANCE OF AMPHIBIANS AND INVASIVE SPECIES IN SOUTHERN GALIFORNIA STREAMS. Seth P. D. Riley ${ }^{1}$, Gary T. Busteed ${ }^{1}$, Lee B. Kats ${ }^{2}$, Thomas L. Vandergon ${ }^{2}$, Lena F. S. Lee $^{1}$, Rosi G. Dagit ${ }^{3}$, Jacob L. Kerby ${ }^{1,3,5}$, Robert N. Fisher ${ }^{4}$, and Raymond M. Sauvajot ${ }^{1}$. ${ }^{1}$ Santa Monica Mountains National Recreation Area, National Park Service, 401 W. Hillcrest Dr., Thousand Oaks, CA 91360; ${ }^{2}$ Department of Biology, Pepperdine University, 24255 Pacific Coast Highway, Malibu, CA 90263; ${ }^{3}$ Resource Conservation District of the Santa Monica Mountains, 122 N. Topanga Canyon Blvd., Topanga, CA 90290; ${ }^{4}$ U.S. Geological Survey, San Diego Field Station, 5745 Kearny Villa Drive, Suite M, San Diego, CA 92123; ${ }^{5}$ Environmental Science and Policy, 1 Shields Ave., University of California, Davis, CA 95616.

6 E 10:20 AMPHIBIAN LIFE IN RESPONSE TO THE AGTIVE REMOVAL OF EXOTIC SPECIES IN STREAMS OF THE SANTA MONICA MOUNTAINS.

L. Kats, S. Rollert, T. Thurling, S. Landis, and D. Cho. Pepperdine University, Department of Biology and Behavioral Ecology, Malibu, CA 90263.

10:40-11:00 BREAK

7 11:00 GALIFORNIA RESPONSE TO THE DISCOVERY OF QUAGGA MUSSEL/ZEBRA MUSSEL IN LAKE MEAD.

S.R. Ellis. California Department of Fish and Game, Habitat Conservation Branch, Sacramento, CA 95814.

8 E 11:20 DISTRIBUTION, HABITAT UTILIZATION, AND REPRODUGTIVE PATTERNS IN CAULACANTHUS USTULATUS (GAULAGANTHAGEAE, GIGARTINALES), A NEWLY ESTABLISHED SEAWEED ON SOUTHERN GALIFORNIA SHORES.

K.E. Whiteside, J.R. Smith, and S. N. Murray. California State University, Fullerton, Department of Biological Science, Fullerton, CA 92834. 
11:40 MANAGING THE SPREAD OF AQUATIC NUISANCE SPEGIES THROUGH HAGCP PLANNING.

Denise A. Walther. Non-native Invasive Species Program, U.S. Fish and Wildlife Service, Stockton Fish and Wildlife Office, Stockton, CA 95205.

12:00-1:20 LUNCH BREAK

Friday, June 1, 2007

Location: ONTIVEROS

Session: Ecological, Environmental and Evolutionary Parasitology

Chair: Donald G. Buth, University of California, Los Angeles

1:20 Introduction, Donald G. Buth

10 1:25 PARASITES IN FOOD WEBS AS BIOINDICATORS OF ENVIRONMENTAL CONDITIONS.

Kevin D. Lafferty. University of California, Santa Barbara, CA 93106.

11 2:00 RELATIONSHIPS BETWEEN ENDOHELMINTH ASSEMBLAGES OF FISH AND WATER QUALITY.

C. Hogue. California State University, Northridge, Department of Biology, Northridge, CA 91330 .

12 2:20 THE BIOMASS OF PARASITES AND THE ENERGETICS OF ECOSYSTEMS.

Armand M. Kuris. University of California, Santa Barbara, CA 93106.

13 2:40 FISH PREDATION ON TREMATODE GERGARIAE IN A GALIFORNIA ESTUARY. Amber T. Kaplan, Sayward E. Halling, Kevin D. Lafferty, and Armand M. Kuris. University of California, Santa Barbara, CA 93106.

3:00-3:20 BREAK

14 3:20 DEVELOPMENT OF ASCAROPHIS SP. (NEMATODA: GYSTIDICOLIDAE) TO MATURITY IN GAMMARUS DEUBENI (AMPHIPODA).

R.G. Appy. Port of Los Angeles, Environmental Management Division, San Pedro, CA 90371.

15 3:40 PARASITE MANIPULATION OF BRAIN MONOAMINES IN KILLIFISH.

J.C. Shaw $^{1}$, W. J. Korzan ${ }^{2}$, R. E. Carpenter ${ }^{3,4}$, A. M. Kuris ${ }^{1}$, K. D. Lafferty ${ }^{5}$, C. H. Summers $^{3,4}$, and Ø. Øverli ${ }^{3,4,6}$. ${ }^{1}$ Department of Ecology, Evolution and Marine Biology, University of California Santa Barbara, CA; ${ }^{2}$ Stanford University, Stanford, CA; ${ }^{3}$ Biology; ${ }^{4}$ Neuroscience Group, Division of Basic Biomedical Sciences, University of South Dakota, Vermillion, SD; ${ }^{5}$ USGS, University of California Santa Barbara, CA; ${ }^{6}$ Department of Animal and Aquacultural Sciences, Norwegian University of Life Sciences, N-1432 Aas, Norway.

16 4:00 THE INFLUENCE OF EGTOPARASITES AND WASTEWATER DISCHARGE ON THE ENDOCRINE STRESS RESPONSE IN MARINE FISHES.

J.E. Kalman, J.A. Reyes, J.L. Armstrong, K. Sak, and K.M. Kelley. California State University, Long Beach, CA; Orange County Sanitation District, Fountain Valley, CA.

17 M 4:20 THE EFFEGTS OF THE EGTOPARASITIC ISOPOD ELTHUSA CALIFORNICA ON THE RESPIRATION OF THE SURF PERGH CYMATOGASTER AGGREGATA

H.D. Johnston, E. Guirges, and E.N. Kageno. University of California, Los Angeles, Department of Evolutionary and Ecological Biology, Los Angeles, CA 90024. 
7:00-8:00 Plenary Lecture. Portola Pavilions $A \& B$.

Dr. Francisco J. Ayala, Donald Bren Professor of Biological Sciences, University of California, Irvine.

\section{DARWIN AND INTELLIGENT DESIGN}

Session: On-Going Paleoenvironmental Studies from Southern California and Surrounding Regions

Chair: Matthew E. Kirby, California State University, Fullerton

HISTORIC MERGURY DEPOSITION WITHIN THREE SOUTHERN GALIFORNIA SITES.

$\underline{\text { Sarah E. Rothenberg }}{ }^{1}$, Matthew E. Kirby ${ }^{2}$, and Jennifer A. Jay ${ }^{3} .{ }^{1}$ Environmental Science and Engineering Program, Box 951772 CHS, University of California, Los Angeles, CA 90095; ${ }^{2}$ Department of Geological Sciences, California State University, Fullerton, CA 92834; ${ }^{3}$ Department of Civil and Environmental Engineering, Box 951593 Boelter Hall, University of California, Los Angeles, CA 90095.

19 P 9:00 HIGH-RESOLUTION THIN-SECTION PHOTOMICROGRAPHY ANALYSIS OF A GLAGIAL-AGE SEDIMENT GORE FROM BALDWIN LAKE, SOUTHERN GALIFORNIA: A LOOK AT SOME INITIAL RESULTS.

Michael Blazevic, Matthew Kirby, Adam Woods, Brandon Browne, and Dave Bowman. California State University, Fullerton, Department of Geological Sciences, Fullerton, CA 92831.

20 9:20 THE PALEOENVIRONMENT OF BURGESS SHALE-TYPE DEPOSITS: FROM SOUTHERN GALIFORNIA TO SOUTH GHINA.

R.R. Gaines. Pomona College, Geology Department, Claremont, CA 91711. DESERT EGOTONE AT JOSHUA TREE NATIONAL PARK

G.A. Holmgren ${ }^{1}$, J.L. Betancourt ${ }^{2}$, and K.A. Rylander ${ }^{2} .{ }^{1}$ California State University, Long Beach, Department of Geography, Long Beach, CA 90840; ${ }^{2}$ U.S. Geological Survey, 1675 W. Anklam Rd., Tucson, AZ 85745.

10:00 CONTEMPORARY WATER QUALITY AND SEDIMENT PROPERTIES OF SOUTHERN GALIFORNIA LAKES.

M.A. Anderson. University of California, Department of Environmental Sciences, Riverside, CA 92521.

10:20 FLOODS, FIRES, AND HUMANS: ASSESSING 150 YEARS OF RAPID DEPOSITIONAL EVENTS IN A SMALL ALPINE LAKE, SOUTHERN GALIFORNIA.

M.E. Kirby ${ }^{1}$, M.B. DeRose ${ }^{1}$, and B.W. Bird ${ }^{2} .{ }^{1}$ California State University, Fullerton, Department of Geological Sciences, Fullerton, CA 92834; ${ }^{2}$ University of Pittsburgh, Department of Earth Sciences, Pittsburgh, PA.

10:40-11:00

$24 \quad 11: 00$

\section{BREAK}

RECONSTRUGTING LATE PLIOGENE TO MIDDLE PLEISTOGENE DEATH VALLEY LAKES AND RIVER SYSTEMS AS A TEST OF PUPFISH (CYPRINODONTIDAE) DISPERSAL HYPOTHESES.

Jeffrey R. Knott. Department of Geological Sciences, California State University, Fullerton, CA 92834. 
11:20 ON-GOING PALEOENVIRONMENTAL STUDIES ON LAKES FROM GENTRAL CALIFORNIA.

R. Negrini ${ }^{1}$, D. Baron ${ }^{1}$, M. Palacios-Fest ${ }^{1}$, P. Wigand ${ }^{1}$, K. O’Sullivan ${ }^{1}$, J. Oseguera ${ }^{1}$, Ben Fleming $^{1}$, Carol Register ${ }^{1}$, Elizabeth Powers ${ }^{1}$, Jason Leiran ${ }^{1}$, Randall Stephenson ${ }^{1}$, Adam Johnson $^{2}$, Lisa Pratt ${ }^{2}$, and Dallas Rhodes ${ }^{3}$. ${ }^{1}$ California State University, Bakersfield, CA 93301; ${ }^{2}$ Indiana University, Bloomington, Indiana 47405; ${ }^{3}$ Georgia Southern University, Statesboro, GA 30460.

11:40 LATE PLEISTOGENE PLUVIAL LAKES OF THE OWENS RIVER GASGADE, CALIFORNIA: THE RELATIVE ROLES OF TECTONIC AND GLIMATIC FORGING. Antony R. Orme ${ }^{1}$ and Amalie Jo Orme ${ }^{2}$. ${ }^{1}$ Department of Geography, University of California, Los Angeles, CA 90095; ${ }^{2}$ Department of Geography, California State University, Northridge, CA 91330

12:00-1:20 LUNCH BREAK

Friday, June 1, 2007

Location: HETEBRINK

Session: Prehistoric and Historic Impacts on the Environment

Chair: Steven R. James and Edgar Huerta, California State University, Fullerton

1:20 INTRODUCTION: PREHISTORIC AND HISTORIC ENVIRONMENTAL IMPACTS.

S.R. James. Department of Anthropology, California State University, Fullerton, P.O. Box 6846, Fullerton, CA 92834.

27 1:40 LATE PREHISTORIC HUMAN IMPAGTS ON MARINE FAUNA IN SOUTHERN CALIFORNIA: AN EXAMPLE FROM SAN NICOLAS ISLAND IN THE SOUTHERN GHANNEL ISLANDS.

S. R. James. Department of Anthropology, California State University, Fullerton, P.O. Box 6846, Fullerton, CA 92834.

28 2:00 PREHISTORIC MARINE ADAPTATION AND POSSIBLE TRENDS OF OVEREXPLOITATION ON SAN NICOLAS ISLAND.

James Wallace. Department of Anthropology, California State University, Fullerton, $800 \mathrm{~N}$. State College Blvd., Fullerton, CA 92831.

29 2:20 FIXING THE LANDSGAPE IN PLAGE: TAKIG PLACE NAMES AND NATURAL RESOURGES.

Stephen O'Neil. SWCA Environmental Consultants, 23392 Madera, Suite L, Mission Viejo, CA 92691.

30 2:40 BURIED SITES ARGHAEOLOGY: LIFE BY THE LAKES IN LAGUNA GANYON DURING THE INTERMEDIATE AND LATE PREHISTORIC PERIODS.

Roderic N. McLean. LSA Associates, Inc., 20 Executive Park, Suite 200, Irvine, CA 92614.

3:00-3:20 BREAK

31 3:20 PREHISTORIC AND HISTORICAL ENVIRONMENT INTERAGTIONS ALONG SANTA MONICA BAY, CALIFORNIA.

John G. Douglass, Richard Ciolek-Torrello, Benjamin Vargas, Seetha Reddy, Sarah Van Galder, Anne Stoll, and Donn Grenda. Statistical Research, Inc., 21 West Stuart Ave., Redlands, CA 92373. 

THROUGH THE ANALYSIS OF ECONOMIC SYSTEMS DURING THE MIDDLE HOLOGENE IN THE NEWPORT BAY REGION.

Edgar Huerta. Department of Anthropology, California State University, Fullerton, 800 N. State College Blvd., Fullerton, CA 92831.

33 E 4:00 TAPHONOMIC IMPLICATIONS OF DIFFERENTIAL PRESERVATION BETWEEN FRESHWATER FISHES.

John Hash. California State University Bakersfield, Department of Biology, Bakersfield, CA 93311.

5:00-6:45 Poster Session and Wine \& Cheese Social. Courtyard.

7:00-8:00 Plenary Lecture. Portola Pavilions $A \& B$.

Dr. Francisco J. Ayala, Donald Bren Professor of Biological Sciences, University of California, Irvine.

\section{DARWIN AND INTELLIGENT DESIGN}

8:00-9:00 Book-Signing Reception. Chapman Atrium.

Friday, June 1, 2007

Location: GABRIELINO

Session: Ecology, Oceanography and Human Impacts of the Southern California Bight

Chair: Jim Allen, Southern California Coastal Water Research Program (SCCWRP) TON BEACH GENERATING STATION: A REVIEW OF ONGE THROUGH COOLING THEN AND NOW IN THE CONTEXT OF OCEANIC REGIME SHIFT. E.F. Miller ${ }^{1}$, D. Shane Beck ${ }^{1}$, John Steinbeck ${ }^{2}$, Ernesto Calix ${ }^{2}$, Kevin T. Herbinson ${ }^{3}$, and Patrick Tennant ${ }^{4} .{ }^{1} \mathrm{MBC}$ Applied Environmental Sciences, Costa Mesa, CA; ${ }^{2}$ Tenera Environmental, San Luis Obispo, CA; ${ }^{3} \mathrm{ACT}$ Environmental, Inc., Laguna Hills, CA; ${ }^{4}$ Southern California Edison, Rosemead, CA.

8:40 THE RECOVERING PACIFIC SARDINE (SARDINOPS SAGAX) POPULATION AS AN INDICATOR OF LINKAGE BETWEEN THE SOUTHERN GALIFORNIA BIGHT AND THE NORTH PAGIFIC TRANSITION ZONE.

P. E. Smith. Integrative Oceanography Division, Scripps Institution of Oceanography, University of California San Diego, La Jolla, CA 92037.

9:00 CHLORINATED HYDROGARBONS IN PELAGIC FORAGE FISHES AND SQUID OF THE SOUTHERN GALIFORNIA BIGHT.

Erica Jarvis, Kenneth Schiff, Lisa Sabin, and M. James Allen. Southern California Coastal Water Research Project, Costa Mesa, CA.

9:20 VARIATION IN DDT/PCB CONCENTRATIONS IN WHITE CROAKER (GENYONEMUS LINLATUS) IN THE SOUTHERN CALIFORNIA BIGHT: INFLUENES OF LOGATION, BODY SIZE, AND LIPID CONTENT.

D.A. Witting and G. Baker. NOAA Restoration Center, Long Beach, CA; NOAA Damage Assessment Center, Menlo Park, CA. 

THE SOUTHERN GALIFORNIA BIGHT IN 2003.

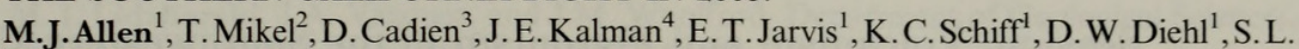
Moore $^{1}$, S. Walther ${ }^{3}$, G. Deets ${ }^{5}$, C. Cash ${ }^{5}$, S. Watts ${ }^{6}$, D. J. Pondella II ${ }^{7}$, V. Raco-Rands ${ }^{1}$, C. Thomas $^{4}$, R. Gartman ${ }^{8}$, L. Sabin ${ }^{1}$, W. Power ${ }^{3}$, A. K. Groce ${ }^{8}$, and J. L. Armstrong ${ }^{4} .{ }^{1}$ Southern California Coastal Water Research Project, Costa Mesa, CA; ${ }^{2}$ Aquatic Bioassay and Consulting Laboratory, Ventura, CA; ${ }^{3}$ County Sanitation Districts of Los Angeles County, Whittier, CA; ${ }^{4}$ Orange County Sanitation District, Fountain Valley, CA; ${ }^{5}$ City of Los Angeles, Environmental Monitoring Division, Playa del Rey, CA; ${ }^{6}$ Weston Solutions, Inc., Port Gamble Environmental Laboratories, Port Gamble, WA; ${ }^{7}$ Occidental College Vantuna Research Group, Department of Biology, Los Angeles, CA; ${ }^{8}$ City of San Diego, Metropolitan Wastewater Department, Marine Biology Laboratory, CA.

10:00 THE GONDITION OF BENTHIC INVERTEBRATE COMMUNITIES IN THE SOUTHERN GALIFORNIA BIGHT.

J.A. Ranasinghe ${ }^{1}$, A.M. Barnett ${ }^{1}$, K. Schiff ${ }^{1}$, D.E. Montagne ${ }^{2}$, C. Brantley ${ }^{2}$, C. Beegan ${ }^{3}$, D.B. Cadien $^{2}$, C. $\mathrm{Cash}^{4}$, D.R. Diener ${ }^{5}$, T.K. $\mathrm{Mikel}^{6}$, R.W. Smith $^{7}$, R.G.Velarde ${ }^{8}$, S.D. Watts ${ }^{9}$, and S.B. Weisberg ${ }^{1} .{ }^{1}$ Southern California Coastal Water Research Project, 3535 Harbor Blvd., Suite 110, Costa Mesa, CA 92626; ${ }^{2}$ County Sanitation Districts of Los Angeles County, P.O. Box 4998, Whittier, CA 90607; ${ }^{3}$ State Water Resources Control Board, Sacramento, CA; ${ }^{4}$ City of Los Angeles, Environmental Monitoring Division, 12000 Vista Del Mar, Playa Del Rey, CA 90293; ${ }^{5}$ P.O. Box 5196, Oceanside, CA 92052; ${ }^{6}$ Aquatic Bioassay and Consulting Laboratories, Inc., 29 North Olive Street, Ventura, CA 93001; ${ }^{7}$ Deceased; ${ }^{8}$ City of San Diego Marine Biology Laboratory, 2392 Kincaid Rd., San Diego, CA 92101; ${ }^{9}$ Weston Solutions, Port Gamble Environmental Laboratories, Port Gamble, WA 98364.

10:20 CHARACTERISTICS OF BENTHIC MAGROFAUNA OF THE SOUTHERN GALIFORNIA BIGHT.

T.K. Mikel ${ }^{1}$, Ananda Ranasinghe ${ }^{2}$, and David E. Montagne ${ }^{3} .{ }^{1}$ Aquatic Bioassay and Consulting Laboratories, Inc., 29 North Olive Street, Ventura, CA 93001; ${ }^{2}$ Southern California Coastal Water Research Project, 3535 Harbor Blvd., Suite 110, Costa Mesa, CA 92626; ${ }^{3}$ County Sanitation District of Los Angeles County, P.O. Box 4998, Whittier, CA 90607.

10:40-11:00

11:00 MARINE ECOLOGICAL MONITORING STUDIES AT GRYSTAL GOVE STATE PARK TO DETERMINE IMPAGTS FROM A GOASTAL DEVELOPMENT PROJEGT.

R. F. Ford ${ }^{1,2}$, M. A. Shane ${ }^{2}$, and J. Kern ${ }^{3}$. ${ }^{1}$ San Diego State University, Biology Department, San Diego, CA 92182; ${ }^{2}$ Hubbs-Sea World Research Institute, 2595 Ingraham Street, San Diego, CA 92109; ${ }^{3}$ Kern Statistical Services, Inc., 5175 NE River Road, Sauk Rapids, MN 56379.

11:20 MODIS IMAGERY AS A TOOL FOR SYNOPTIC WATER QUALITY ASSESSMENTS IN SOUTHERN GALIFORNIA GOASTAL OGEAN.

Nikolay P. Nezlin ${ }^{1}$, Paul M. DiGiacomo ${ }^{2}$, Burton H. Jones ${ }^{3}$, Kristen M. Reifel ${ }^{3}$, Scott C. Johnson $^{4}$, Mike Mengel ${ }^{5}$, and Jonathan A. Warrick ${ }^{6}$. ${ }^{1}$ Southern California Coastal Water Research Project, Costa Mesa, CA 92626; ${ }^{2}$ NOAA/NESDIS Center for Satellite Applications and Research (STAR), Camp Springs, MD 20746; ${ }^{3}$ Department of Biological Sciences, University of Southern California, Los Angeles, CA 90089; ${ }^{4}$ Aquatic Bioassay and Consulting Laboratories, Ventura, CA 93001; ${ }^{5}$ Orange County Sanitation District (OCSD), Fountain Valley, CA 92728; ${ }^{6}$ USGS Coastal and Marine Geology Program, Santa Cruz, CA 95060.

11:40 SETTING UP A WATER QUALITY MONITORING NETWORK ALONG THE GALIFORNIA GOASTLINE

A.L. Willingham, L. Gilbane, R. Pieper, and A. Resister. Southern California Marine Institute, CICORE (Center for Integrative Coastal Observation Research and Education), San Pedro, CA 90731. 
Friday, June 1, 2007

Location: BRADFORD

Session: Volcanism and Plutonism in the Southwestern U.S.

Chair: Brandon Browne, California State University, Fullerton

44 2:00 CONTRASTING BASALTIG ERUPTION STYLES OBSERVED AT RED CONES, EASTERN SIERRA NEVADA.

B.L. Browne, M. Louros, and A. Martos. California State University Fullerton, Department of Geological Sciences, Fullerton, CA 92834.

45 P 2:20 PETROLOGIC CONSTRAINTS ON ERUPTION TRIGGERING AT MAMMOTH MOUNTAIN, GALIFORNIA.

G. Terpolilli and B. Browne. California State University, Fullerton, Department of Geological Sciences, Fullerton, CA 92834.

46 2:40 U-PB DATING OF ZIRGON GRYSTALLIZATION IN THE HOT GREEK RHYOLITE, LONG VALLEY GALDERA, GALIFORNIA: NO GRYSTAL MEMORY OF BISHOP TUFF MAGMA.

J.A. Vazquez and C. Gainer. Department of Geological Sciences, California State University, Northridge, CA 91330.

3:00-3:20 BREAK

3:20-4:30 THE FOLLOWING POSTERS RELATING TO THIS SESSION WILL BE PRESENTED BY THEIR AUTHORS. Courtyard.

NEOGENE ALKALINE/SUBALKALINE VOLCANISM IN THE EASTERN MOJAVE PROVINGE.

S.M. Baltzer and D.R. Jessey. Geological Sciences Department, California State Polytechnic University, Pomona, CA 91768.

$48 \mathrm{P}$

VOLGANIC PETROLOGY, GEOCHEMISTRY AND STRATIGRAPHY OF THE GRANDE SOUFRIERE HILLS VOLGANO, DOMINICA, WEST INDIES.

G.E. Daly and A.L. Smith. California State University, San Bernardino, Department of Geological Sciences, San Bernardino, CA 92407.

PALEOMAGNETIC EVIDENCE FOR TIMESCALES OF MULTI-VENT BASALTIC ERUPTIONS IN BIG PINE VOLCANIC FIELD, CALIFORNIA.

A. Zohar and E. Nagy-Shadman. California State University, Northridge, Department of Geological Sciences, Northridge, CA 91330.

CONSTRAINING THE RATE AND STYLE OF MAGMA ASCENT AT MAMMOTH MOUNTAIN, EASTERN GALIFORNIA.

G. Wolfe and B. Browne. California State University, Fullerton, Department of Geological Sciences, Fullerton, CA 92834.

BASALTIC VOLGANISM AND VOLGANIC HAZARDS AT BIG PINE VOLGANIC FIELD, INYO GOUNTY, GALIFORNIA.

Jeffrey M. Woolford and Jorge Vazquez. Department of Geological Sciences, California State University, Northridge, 18111 Nordhoff St., Northridge, CA 91330.

FIELD RELATIONSHIPS AND MINERAL ABUNDANGES OF THE 5000 YEAR OLD BASALTS ERUPTED FROM RED CONES VOLGANOES, GALIFORNIA.

A. Martos, M. Louros, and B. Browne. California State University Fullerton, Department of Geological Sciences, Fullerton, CA 92834. 

CALIFORNIA.

M. I. Lidzbarski, J.A. Vazquez, and J.M. Woolford. Department of Geological Sciences, California State University, Northridge, CA 91330.

M.W. Lusk and D.R. Jessey. Geological Sciences Department, California State Polytechnic University, Pomona, CA 91768.

PHYSICAL AND CHEMICAL CHARACTERISTICS OF VOLCANIC HOTSPRINGS AT WOTTEN WAVEN, DOMINICA, LESSER ANTILLES.

R. Herlihy, J.E. Fryxell, and A.L. Smith. California State University, San Bernardino, Department of Geological Sciences, San Bernardino, CA 92407.

$56 \mathrm{P}$

$5: 00-6: 45$

7:00-8:00

8:00-9:00

ERUPTIVE HISTORY OF SOUFRIERE VOLGANO, ST. VINCENT AS ILLUSTRATED BY THREE PYROGLASTIG SEQUENGES.

L.J. Estrella and A.L. Smith. Department of Geological Sciences, California State University, San Bernardino, CA 92407.

Poster Session and Wine \& Cheese Social. Courtyard.

Plenary Lecture. Portola Pavilions $A \& B$.

Dr. Francisco J. Ayala, Donald Bren Professor of Biological Sciences, University of California, Irvine.

\title{
DARWIN AND INTELLIGENT DESIGN
}

\author{
Book-Signing Reception. Chapman Atrium.
}

\section{Friday, June 1, 2007 \\ Location: GILMAN}

\section{Session: Contributed Papers}

57 E 9:00 IMMIGRATION IN THE OCEAN: STATOLITHS AS LARVAL PASSPORTS.

$\underline{\text { S.E. Koch }}^{1}$, G. Paradis ${ }^{2}$, S.D. Gaines ${ }^{2}$, R.R. Warner ${ }^{2}$, and D.C. Zacherl ${ }^{1}{ }^{1}$ Department of

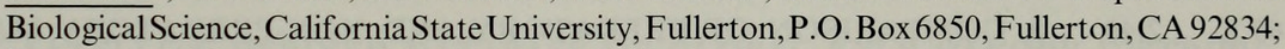
${ }^{2}$ Department of Ecology, Evolution and Marine Biology, University of California, Santa Barbara, CA 93101.

58 E 9:20 GLOBAL POPULATION STRUCTURE OF THE TOPE (GALEORHINUS GALEUS), AS INFERRED BY MITOCHONDRIAL CONTROL REGION SEQUENCE DATA.

G.L. Chabot. Nearshore Marine Fish Research Program, California State University, Northridge, Department of Biology, Northridge, CA 91330.

59 E 9:40 REPRODUCTIVE LONGEVITY IN THE POLYGHAETOUS ANNELID DINOPHILUS GYROCILIATUS.

Jessica Dewar and Cheryl Bube. Department of Biological Sciences, California State University, Long Beach, CA 90840.

$60 \mathrm{E}$ 10:00 THE MECHANISM OF MALE GHOICE IN THE SEMELPAROUS POLYGHAETE NEANTHES ACUMINATA.

Ellen J. Storey. Department of Biological Sciences, University of Hull, Cunningham Road, Hull, United Kingdom, HU6 7RX.

$61 \mathrm{E}$ 10:20 TO SETTLE OR NOT TO SETTLE: SEASONAL SETTLEMENT OF OYSTER LARVAE, OSTREA CONCHAPHILA, IN TWO SOUTHERN GALIFORNIA ESTUARIES.

E. M. Seale and D. C. Zacherl. Southern California Ecosystems Research Program, California State University, Fullerton, CA 92834. 
10:40-11:00

$62 \mathrm{~F} \quad 11: 00$

BREAK

MEDIAL RED MUSGLE DEVELOPMENT IN THE YELLOWFIN TUNA (THUNNUS ALBACARES).

J. M. Dickson and K. A. Dickson. Department of Biological Science, California State University, Fullerton, CA 92831.

$63 \mathrm{~F}$ 11:20 AN EMBRYONIG STAGING SERIES FOR THE GALIFORNIA GRUNION, LEURESTHES TENUIS.

G. L. Moravek, J. A. Flannery, and K. L. Martin. Pepperdine University, Department of Biology, Malibu, CA 90263.

64 F 11:40 MICROSATELLITE AND MORPHOLOGICAL INVESTIGATION OF AN APPARENTLY DISJUNCT NORTHERN POPULATION OF GALIFORNIA GRUNION, LEURESTHES TENUIS.

P.B. Johnson, T. Vandergon, R. Honeycutt, and K. Martin. Pepperdine University, Department of Biology, Malibu, CA 90263.

12:00-1:20 LUNCH BREAK

65 1:20 RECIPE: A NOVEL RESEARCH PROJEGT THAT IS MORE THAN HALF-BAKED. A. Dalkey. Palos Verdes Peninsula Land Conservancy, 916 Silver Spur Road \#207, Rolling Hills Estates, CA 90274.

66 1:40 EFFECTS OF A PURPOSE-BUILT UNDERPASS ON WILDLIFE ACTIVITY AND TRAFFIC-RELATED MORTALITY IN SOUTHERN CALIFORNIA: THE HARBOR BOULEVARD WILDLIFE UNDERPASS.

David Elliott and Paul Stapp. Department of Biological Science, California State University, Fullerton, CA 92834.

67 E 2:00 ETHNOBOTANY IN THE GANADIAN ARGTIC: A SURVEY OF THE COPPER INUIT. J.D. Davis and S. A. Banack. California State University, Fullerton, Department of Biological Science, Fullerton, CA 92831.

$68 \mathrm{E}$ 2:20 MALE GRICKET AGGRESSION AND PREDATION RISK: MALE GRIGKETS FIGHTING OVER SPIDER SILK.

L. J. Buena and S. E. Walker. California State University, Fullerton, Department of Biological Science, Fullerton, CA 92831.

69 E 2:40 A COMPARISON OF PREDATORY AND NON-PREDATORY MAMMAL MANAGEMENT POLICIES IN THE ELEVEN WESTERN STATES.

J.B. Litvak. California State University, Fullerton, Department of Environmental Studies, Fullerton, CA 92834.

$3: 00-3: 20$

BREAK

$70 \mathrm{E}$ 3:20 MOTH DIVERSITY ALONG AN ELEVATIONAL GRADIENT IN SOUTHEAST ARIZONA.

G. Francois and S. E. Walker. California State University, Fullerton, Department of Biological Science, Fullerton, CA 92834.

$71 \quad 3: 40$

DIFFERENTIALLY ALTERING THE ABILITY OF HAEMOPHILUS INFLUENZAE TO FORM BIOFILMS BY USING SUBTHERAPEUTIC DOSES OF MULTIPLE ANTIBIOTICS.

Yamila Hernandez, Ken Bradley, and Robert Damoiseaux. Palos Verdes Peninsula, 27118 Silver Spur Rd., Rolling Hills Estates, CA 90274; University of California, Los Angeles, Molecular Sciences Department, Los Angeles, CA 90095.

IS YOUR BEACH IN HOT WATER? WARMING WATER TEMPERATURES GAUSE ERRONEOUS BACTERIAL EXCEEDANCES USING STANDARD BACTERIAL METHODS.

L.A.A. Aumand, A.L. Trinh, and T.K. Smith-Kruck. Weston Solutions, Inc., Microbial Sciences Laboratories, 2433 Impala Dr., Carlsbad, CA 92010. 
73 E 4:20 CONSEQUENGES OF MANY GENERATIONS OF HYBRIDIZATION UNDER BOTH STRESSFUL AND BENIGN GONDITIONS.

A. S. Hwang and S. Edmands. University of Southern California, Department of Biological Sciences, Los Angeles, CA 90089.

105 E 4:40 GONTROLS ON PLANT GAS EXGHANGE ACROSS A GRASSLAND TO SHRUBLAND GRADIENT IN OWENS VALLEY, GALIFORNIA.

C.M. Goedhart ${ }^{1}$, D.E. Pataki ${ }^{1}$, and S.A. Billings ${ }^{2} .{ }^{1}$ University of California, Irvine, Department of Ecology and Evolutionary Biology, Irvine, CA 92697; ${ }^{2}$ University of Kansas, Department of Ecology and Evolutionary Biology, Lawrence, KS 66045.

5:00-6:45 Poster Session and Wine \& Cheese Social. Courtyard.

7:00-8:00 Plenary Lecture. Portola Pavilions $A \& B$.

Dr. Francisco J. Ayala,

Donald Bren Professor of Biological Sciences, University of California, Irvine.

\section{DARWIN AND INTELLIGENT DESIGN}

8:00-9:00 Book-Signing Reception. Chapman Atrium.

Friday, June 1, 2007

Location: ALVARADO

Session: Biology of Rocky Reefs

Chair: Dan Pondella, Occidental College, and Robert Grove, Southern California Edison

11:00 PERSISTENCE AND ITS LIMITING FACTORS IN SOUTHERN GALIFORNIA KELP BEDS.

Michael D. Gurtis. Senior Scientist, MBC Applied Environmental Sciences, Costa Mesa, CA.

11:20 A SATELLITE DERIVED DATABASE OF GLOBAL KELP GANOPY DISTRIBUTION.

Larry Deysher. PO Box 232296, Leucadia, CA 92023.

76 E 11:40 PHOTOACGLIMATION ALONG A VERTICAL GRADIENT IN DIFFERENT GROWTH STAGES IN THE ELK KELP, PELAGOPHYCUS PORRA.

Stacie M. Fejtek ${ }^{1}$, Matthew S. Edwards ${ }^{1}$, and Kwan-Young Kim ${ }^{2}$. ${ }^{1}$ Department of Biology, San Diego State University, San Diego, CA; ${ }^{2}$ Department of Oceanography, Chonnam National University, Gwangju, Korea.

12:00-1:20 LUNGH BREAK

77 1:40 GOMMUNITY-BASED GIANT KELP RESTORATION AND MONITORING IN ORANGE GOUNTY, GALIFORNIA.

N.L. Caruso. Kelp Project Manager, California Coastkeeper Alliance, PO Box 3156, Fremont, CA 94539.

78 2:00 RESTORED KELP BEDS OFF OF MALIBU AND PROGRESS OFF PALOS VERDES, WORTH DIVING FOR.

T. Ford. Santa Monica Baykeeper Kelp Restoration and Monitoring Project, P.O. Box 10096, Marina Del Rey, CA 90295. 
$79 \mathrm{E}$ 2:20 FISH-HABITAT ASSOGIATIONS AND THE ROLE OF DISTURBANGE IN SURFGRASS BEDS.

Garey J. Galst. San Diego State University, Department of Biology, San Diego, CA 92182.

81 2:40 EXTRAPOLATING RESULTS OF SMALL-SGALE FIELD EXPERIMENTS TO ENHANCE POPULATIONS OF A CORAL REEF FISH AT LARGE SPATIAL SCALES.

Mark A. Steele and Graham E. Forrester. Department of Biology, California State University, Northridge, CA 91330; Department of Natural Resources Science, University of Rhode Island, Kingston, RI 02881.

3:00-3:20 BREAK

82 F 3:20 - THE RELATIVE EFFECTS OF BIOGEOGRAPHY AND SIZE-SELEGTIVE FISHING PRESSURE ON THE POPULATION STRUCTURE AND SEX-CHANGE DYNAMICS OF THE CALIFORNIA SHEEPHEAD, SEMICOSSYPHUS PULCHER.

L.S. Wetmore. Vantuna Research Group, Occidental College, Department of Biology, Los Angeles, CA 90041.

3:40 ISOLATING THE EFFEGTS OF LARVAL SOURGE ON THE POPULATION OF A MARINE INVERTEBRATE

S.C. Schroeter ${ }^{1}$, D. Reed ${ }^{1}$, and P. Raimondi ${ }^{2} .{ }^{1}$ Marine Science Institute, University of California, Santa Barbara, CA 93106; ${ }^{2}$ Department of Ecology and Evolutionary Biology, University of California, Santa Cruz, CA.

4:00 DEMOGRAPHIC PARAMETERS OF YELLOWFIN CROAKER, UMBRINA RONCADOR (PERCIFORMES: SCIAENIDAE) FROM THE SOUTHERN CALIFORNIA BIGHT.

$\underline{\text { D. J. Pondella, II }}^{1}$, J. T. Froeschke ${ }^{2}$, L. S. Wetmore ${ }^{1}$, E. Miller ${ }^{3}$, C. F. Valle ${ }^{4}$, and Lea Medeiros ${ }^{1}$. ${ }^{1}$ Vantuna Research Group and Department of Biology, Moore Laboratory of Zoology, Occidental College, Los Angeles, CA 90041; ${ }^{2}$ Texas A\&M University - Corpus Christi, TX; ${ }^{3} \mathrm{MBC}$ Applied Environmental Sciences; ${ }^{4}$ California Department of Fish and Game. ÁNGELES, BAJA CALIFORNIA, MEXICO (2005-2007).

Jorge A. Rosales-Casian ${ }^{1}$ and Phillip A. Hastings ${ }^{2} .{ }^{1}$ Departamento de Ecología, Grupo de Ecología Pesquera, Centro de Investigación Científica y Educación Superior de Ensenada (CICESE), Km 107 carretera Tijuana-Ensenada, Ensenada, Baja California, México; ${ }^{2}$ Scripps Institution of Oceanography, University of California San Diego, 9500 Gilman Dr., La Jolla, CA 92093.

4:40 IMPACTS OF HABITAT USE ON CONTAMINANT CONGENTRATIONS IN SEVERAL SPEGIES OF FISHES GOLLECTED IN THE PALOS VERDES SUPERFUND SITE.

D.A. Witting and G. Baker. NOAA Restoration Center, Long Beach, CA; NOAA Damage Assessment Center, Menlo Park, CA.

5:00-6:45 Poster Session and Wine \& Cheese Social. Courtyard.

7:00-8:00 Plenary Lecture. Portola Pavilions $A \& B$.

Dr. Francisco J. Ayala,

Donald Bren Professor of Biological Sciences, University of California, Irvine.

\section{DARWIN AND INTELLIGENT DESIGN}

8:00-9:00 Book-Signing Reception. Chapman Atrium. 
Friday, June 1, 2007

Location: COURTYARD

Session: Poster Session, 5:00-6:45 p.m.

SEE PAPERS 47-56 FOR ADDITIONAL POSTERS

87

$88 \mathrm{M}$

89

$90 \mathrm{P}$

$91 \mathrm{M}$

$92 \mathrm{E}$

93

$94 \mathrm{M}$

$95 \mathrm{E}$

96

$97 \mathrm{E}$

BALLONA WETLANDS - BOLD VEGETATION GIS MAPPING PROJEGT.

Ned Bader and Pippa Drennan. Loyola Marymount University, College of Science and Engineering, Los Angeles, CA 90045.

THE EFFECT OF DL-HOMOGYSTEINE ON MINERALIZATION IN OSTEOBLAST-LIKE GELL GULTURES.

M. Barakat, S. Choi, E.J. Jung, and E.E. Joseph. La Sierra University, Department of Biology, Riverside, CA 92505.

NEUROTOXINS IN OUR ENVIRONMENT.

T. Buretta and S. Banack. Institute for Ethnomedicine, California State University Fullerton, Department of Biological Science, Fullerton, CA 92831.

EVIDENCE FOR RAPID LAKE LEVEL GHANGE DURING THE LAST GLAGIAL MAXIMUM IN SOUTHERN GALIFORNIA (LAKE ELSINORE).

J.E. Carrasco, M.E. Kirby, and S.P. Lund. California State University, Fullerton, Department of Geological Sciences, Fullerton, CA 92831.

BURST SWIMMING PERFORMANCE AND METABOLIC ENZYME ACTIVITIES IN LARVAL AND JUVENILE WHITE SEABASS (ATRACTOSCION NOBILIS).

A. Garrillo and K. A. Dickson. Southern California Ecosystem Research Program, Department of Biological Science, California State University, Fullerton, CA 92834.

SONG RECOGNITION IN PLAYBAGK EXPERIMENTS IN ANNA'S HUMMINGBIRD, CALYPTE ANNA.

Carina Gastro and Anne Houtman. Southern California Ecosystem Research Program, California State University, Fullerton, Department of Biological Science, Fullerton, CA92831.

BMAA, A NEUROTOXIN IN THE TRADITIONAL GHAMORRO FOOD.

R. Cheng, M. Suazo, and S. Banack. Institute for Ethnomedicine, California State University Fullerton, Department of Biological Science, Fullerton, CA 92831.

CHARACTERIZING THE UPSTREAM REGULATORY REGION OF BP180.

Jennifer Cherone and Amy Soto. Andersen Laboratory, University of California Irvine, Departments of Medicine (Endocrinology) and Biological Chemistry, Irvine, CA 92697.

AGGRESSION AND BIG HEADS: SEXUAL DIMORPHISM IN HOUSE GRICKETS (ACHETA DOMESTICUS).

G. J. Collins, I. Adame, D. Lim, and S. E. Walker. Department of Biological Science, California State University, Fullerton, CA 92831.

DOGUMENTATION OF GOYOTES ON THE PALOS VERDES PENINSULA.

Ann Dalkey ${ }^{1}$ and Rebecca Niemiec ${ }^{2} .{ }^{1}$ Palos Verdes Peninsula Land Conservancy, 916 Silver Spur Road \#207, Rolling Hills Estates, CA 90274; ${ }^{2}$ Chadwick High School, 26800 S. Academy Drive, Palos Verdes Peninsula, CA 90274.

HAS THE STATEWIDE BAN ON CAULERPA SPEGIES BEEN EFFEGTIVE? A SURVEY OF SOUTHERN GALIFORNIA AQUARIUM RETAIL STORES.

S.H. Diaz $^{1}$, S.F. Zaleski ${ }^{2}$, J.R. Smith ${ }^{1}$, and S.N. Murray ${ }^{1} .{ }^{1}$ Department of Biological Science, California State University, Fullerton, CA 92834; ${ }^{2}$ Sea Grant Program, University of Southern California, Los Angeles, CA 90089. 
S.C. Dobbie. Ecology and Paleoecology Research Group, Department of Life Sciences, Pasadena City College, CA 91106.

ETHYLENE AS A POSSIBLE GERMINATION GUE FOR SAND VERBENAS (ABRONIA SPP., NYGTAGINACEAE).

Philippa M. Drennan and Kristine Tulio. Loyola Marymount University, Department of Biology, Los Angeles, CA 90045.

FIRES OF KELVIN GANYON.

L.E. Eckert. California Polytechnic State University, Earth and Soil Sciences Department, San Luis Obispo, CA 93405.

INFLUENGE OF ANTHROPOGENIC NOISE ON SONG STRUCTURE IN ANNA'S AND COSTA'S HUMMINGBIRDS.

Sarah English and Anne Houtman. Department of Biological Science, California State University, Fullerton, CA 92834.

$102 \mathrm{E}$

THE EFFECTS OF HYDROPERIOD ON THE GROWTH RATES OF FLORIDA FLAGFISH, JORDANELLA FLORIDAE, IN THE FLORIDA EVERGLADES.

S.M. Estes ${ }^{1}$ and J.C. Trexler ${ }^{2}$. ${ }^{1}$ University of California, Department of Ecology and

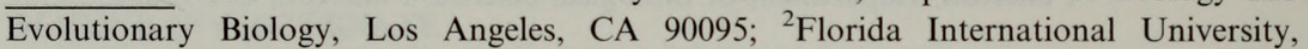
Department of Biological Sciences, Miami, FL 33199.

GEOCHRONOLOGY AND PALEOENVIRONMENT OF PLUVIAL HARPER LAKE, MOJAVE DESERT, GALIFORNIA.

Anna L. Garcia and Jeffrey R. Knott. California State University, Fullerton, Department of Geological Sciences, Fullerton, CA 92831.

POSSIBLE HEAT SOURGES FOR GRANIAL ENDOTHERMY IN THE YELLOWFIN TUNA.

M. Garcia, I.M. Buan, R. Runcie, and K.A. Dickson. Department of Biological Science, California State University, Fullerton, CA 92834.

THE EFFECTS OF GLYPHOSATE ON PROLIFERATION OF RANA PIPIENS SPLENOGYTES STIMULATED WITH CON A AND PHA.

Jeannie Gonzalez and Christine Broussard. Department of Biology, University of La Verne, La Verne, CA 91750.

10-YEAR ASSESSMENT OF SOFT-BOTTOM MACROBENTHIC ASSEMBLAGES OFF THE COAST OF SAN DIEGO.

R.N. Haring, T.D. Stebbins, D. Pasko, and D. James. City of San Diego Marine Biology Laboratory, Environmental Monitoring \& Technical Services Division, Metropolitan Wastewater Department, San Diego, CA.

$108 \mathrm{~F}$ LENGTH, WEIGHT AND GENDER GOMPARISONS OF THE BAY PIPEFISH (SYNGNATHUS LEPTORHYNCHUS) FROM THREE CENTRAL GALIFORNIA COASTAL LOGATIONS.

M. Kodama, B. Lau, and J. M. Vallejo. University of California, Los Angeles, Department of Ecology and Evolutionary Biology, Los Angeles, CA 90095.

$109 \mathrm{E}$

PREDATION IN EELGRASS BEDS: DO TROPHIC MANIPULATIONS RESULT IN GASCADING EFFECTS?.

L.S. Lewis and T.W. Anderson. Fish Ecology Lab, San Diego State University, Department of Biology, San Diego, CA 92182.

THE EFFECTS OF STRESS AND EXERCISE ON THE EXPRESSION OF BCL-2 ASSOCIATED PROTEIN $X$ AND BRAIN-DERIVED NEUROTROPHIC FAGTOR.

H. T. Luu ${ }^{1}$, D. E. Haack ${ }^{2}$, M.J. Chen ${ }^{2}$, and A. Russo-Neustadt ${ }^{2} .{ }^{1}$ Alhambra High School, Alhambra, CA 91801; ${ }^{2}$ Department of Biological Sciences, California State University, Los Angeles, CA 90032. 
FEEDING RATES OF NATIVE GONSUMERS ON INTRODUCED AND NATIVE SEAWEEDS ON URBAN SOUTHERN GALIFORNIA SHORES.

G.N. Navarro, J.R. Smith, and S.N. Murray. California State University Fullerton, Department of Biological Science, Fullerton, CA 92834.

$112 \mathrm{E}$ PREDICTORS OF SUGGESSION IN A CHRONOSEQUENGE OF IMPERATA INFESTED COMMUNITIES.

A.M. Nishimura. University of California, Los Angeles, Department of Ecology and Evolutionary Biology, Los Angeles, CA 90095.

THE EFFECTS OF SODIUM BUTYRATE ON THE ORGANIZATION OF AGTIN FILAMENTS IN U87MG BRAIN TUMOR GELLS.

I. Oh, E. Liu, and J. Wilson. La Sierra University, Department of Biology, Riverside, CA 92515

$114 \mathrm{M}$

HYPOCHLORITE-INDUGED DEATH REVEALS THAT MICROPYLAR GELL DIVISION IS NOT NEGESSARY FOR DEVELOPMENT OF SPATHOGLOTTIS PLICATA SEEDLINGS.

R.S. Pardiwala and S. Darling Novak. University of La Verne, Department of Biology, La Verne, CA 91750.

$115 \mathrm{E}$ THE EFFEGTS OF AN INVASIVE PLANT SPEGIES, VINCA MAJOR, ON ARTHROPOD COMMUNITIES IN RIPARIAN HABITAT AT STARR RANCH AUDUBON SANCTUARY, GALIFORNIA.

E.S. Peralta and S.E. Walker. Southern California Ecosystems Research Program, California State University, Fullerton, Department of Biology, Fullerton, CA 92831.

THE POPULATION GENETICS OF ROUND STINGRAYS FROM SOUTHERN CALIFORNIA ASSESSED BY MICROSATELLITE MARKERS.

S.M. Plank, C.G. Lowe, and J.A. Brusslan. California State University Long Beach, 1250 Bellflower Blvd., Long Beach, CA 90840.

FEEDING PREFERENCES OF THE MARINE GASTROPOD APLYSIA VACCARIA.

M. R. Raith and D. C. Zacherl. Southern California Ecosystems Research Program, California State University, Fullerton, CA 92834.

INDUGED OXIDATIVE STRESS DEGREASES MINERALIZATION IN BONE-LIKE GELL GULTURES.

M. Rauf, A. Heyn, S. Torres, and E.E. Joseph. La Sierra University, Department of Biology, Riverside, CA 92505.

GOMPARISON OF THREE ANALYTICAL METHODS TO DETERMINE GHLOROPHYLL GONGENTRATION IN THE OGEAN.

A.L. Register, L. Gilbane, and R. Pieper. Southern California Marine Institute, CICORE (Center for Integrative Coastal Observation Research \& Education), San Pedro, CA 90731.

COMMUNITY STRUGTURE OF MAGROPARASITES OF THE VERMILION ROCKFISH, SEBASTES MINIATUS, FROM REGREATIONAL FISHING GATCHES OF SAN QUINTÍN, BAJA GALIFORNIA, MEXICO.

M.A. Rodriguez-Santiago ${ }^{1}$ and J.A. Rosales-Casián ${ }^{2}$. ${ }^{1}$ Facultad de Ciencias Marinas (UABC), Km 106 carretera Tijuana-Ensenada, Ensenada, Baja California, México, C.P. 22800; ${ }^{2}$ Departamento de Ecología, Grupo de Ecología Pesquera, Centro de Investigación Científica y Educación Superior de Ensenada (CICESE), Km 107 carretera TijuanaEnsenada, Ensenada, Baja California, México, C.P. 22800.

$121 \mathrm{E}$ TEMPORAL AND SPATIAL VARIATION IN SETTLEMENT OF OSTREA CONCHAPHILA IN NEWPORT BAY, GALIFORNIA.

Lily A. Sam and Danielle Zacherl. Southern California Ecosystems Research Program, Department of Biological Science, California State University, Fullerton, CA 92831. 
THE EFFEGTS OF SODIUM BUTYRATE ON U87MG BRAIN TUMOR GELL MIGRATION AND INVASION.

G. Shaw, M. Sirichotiratana, A. Mesipam, and J. Wilson. La Sierra University, Department of Biology, Riverside, CA 92515. SANTA MONICA BAY.

A. Corcoran and R. Shipe. University of California Los Angeles, Department of Ecology and Evolutionary Biology \& the Institute of the Environment, Los Angeles, CA 90095.

EFFECT OF TEMPERATURE AND RATION LEVEL ON THE GROWTH OF YOUNG-OF-THE YEAR COHO SALMON (ONCORHYNCHUS KISUTCH): A COMPARISON BETWEEN OREGON AND GENTRAL GALIFORNIA STOCKS.

Erick A. Sturm, John M. Silveus, and R. Bruce MacFarlane. National Marine Fisheries Service, 110 Shaffer Road, Santa Cruz, CA 95060.

PERCENT METHYLATION AND ITS RELATIONSHIP WITH AGING.

Shelly Tat and Dr. Shibata. USC Norris Cancer Center, 1441 Eastlake Ave., Los Angeles, CA 90033.

DETERMINING THE TIMING AND OFFSET OF SECONDARY NORMAL FAULTS IN THE KIT FOX HILLS ADJACENT THE NORTHERN DEATH VALLEY FAULT ZONE.

B.M. Taylor and J.R. Knott. California State University Fullerton, Department of Geological Sciences, Fullerton, CA 92831.

127 F DEVELOPMENT OF JAW MUSGULO-SKELETAL STRUGTURE IN THE YELLOWFIN TUNA AND THE EASTERN PACIFIC BONITO.

S. Truong and K.A. Dickson. Department of Biological Science, California State University, Fullerton, CA 92831.

$128 \mathrm{E}$

MORPHOLOGICAL VARIATION OF YUCCA BREVIFOLIA (AGAVACEAE) AMONG SEVEN POPULATIONS IN THE MOJAVE DESERT.

T. R. Valentovich and D. R. Sandquist. California State University, Fullerton, Department of Biological Science, Fullerton, CA 92831.

$129 \mathrm{M}$ THE ACETYLCHOLINESTERASE INHIBITOR MALATHION IS NOT TOXIC TO THYMOGYTES, BUT MAY ALTER THE DEVELOPMENTAL PROGRAM AT LOW DOSES.

Christine Broussard and Jessica Varney. Department of Biology, University of La Verne, La Verne, CA 91750.

$130 \mathrm{M}$ EFFECTS OF METHOXYGHLOR EXPOSURE ON THE DEVELOPMENT OF CD4 T-GELLS IN C57BL/6 MICE.

A.J. Vasa and Christine Broussard. Department of Biology, University of La Verne, La Verne, CA 91750.

GOMPUTATIONAL ANALYSIS OF GRAINYHEAD-LIKE EPITHELIAL TRANSAGTIVATOR (GET1) REGULATED GENES.

Madhvi Venkatesh, Ambica Bhandari, and Bogi Andersen. University of California, Department of Biological Chemistry, Irvine, CA 92697.

THE EFFECTS OF SODIUM BUTYRATE ON THE SEGRETION OF MATRIX METALLOPROTEINASES BY U87MG BRAIN TUMORS.

B. Villegas, M. Kim, J. Hoang, and J. Wilson. La Sierra University, Department of Biology, Riverside, CA 92515. 
$133 \mathrm{E}$

$134 \mathrm{E}$

135

137

136 A STUDY OF FEGAL INDICATOR BACTERIA IN THE BALLONA WETLANDS

EXPERIMENTAL RESTORATION OF THE ROGKY INTERTIDAL BROWN ALGA SILVETIA COMPRESSA ON URBAN SOUTHERN GALIFORNIA SHORES.

Stephen G. Whitaker, J.R. Smith, and S.N. Murray. California State University Fullerton, Department of Biological Science, Fullerton, CA 92834.

SPATIAL AND TEMPORAL VARIATION IN $\delta^{13} \mathrm{C}$ AND $\delta^{15} \mathrm{~N}$ VALUES OF MACROALGAE IN SOUTHERN GALIFORNIA WATERS.

S.C. Vogt. ${ }^{1}$, L. Gilbane ${ }^{2}$, A. Bullard ${ }^{1}$, J.R. Smith ${ }^{1}$, and S.N. Murray ${ }^{1}$. ${ }^{1}$ Department of Biological Science, California State University, Fullerton, CA 92834; ${ }^{2}$ Southern California Marine Institute, Terminal Island, CA 90731.

HEAT SHOCK PROTEIN 70 (HSP70) EXPRESSION IN MULTIPLE SCLEROSIS.

Amy Young. Multiple Sclerosis Research Group, University of Southern California, Keck School of Medicine, McKibben Hall, 1333 San Pablo Street, Los Angeles, CA 90033. AND DEL REY LAGOON, LOS ANGELES, CALIFORNIA.

S. Yanamadala and J.H. Dorsey. Chadwick School, 26800 S. Academy Drive, Palos Verdes, CA 90274.

GEOGRAPHICAL, TAXONOMICAL, TEMPORAL AND HOST SIZE/AGE GOMPARISONS OF INTESTINAL PARASITES IN THREE SPEGIES OF SCULPINS.

Jonathan Sim, Kathryn Fabella, and Alexander Mack Cruz. University of California, Los Angeles, CA 90095.

Saturday, June 2, 2007

Location: GABRIELINO

Session: Paleontology of Southern California

Chair: Mark Roeder, San Diego Museum of Natural History

138 E 9:00 A TAXONOMIC REVIEW OF LATE CRETACEOUS GIMOLESTIDS.

J.J. Strauss. San Diego State University, Department of Biology, San Diego, CA 92182.

139 9:20 PRELIMINARY REVISION OF AGRIOCHOERID OREODONTS OF SOUTHERN CALIFORNIA.

J. A. Ludtke. San Diego State University, Department of Biology, San Diego, CA 92182.

140 E 9:40 PHYLOGENETIC POSITION AND BIOGEOGRAPHICAL IMPLICATIONS OF SOUTHERN GALIFORNIA TORTOISES.

C.B. Jones. San Diego State University, Department of Biology, San Diego, CA 92182.

141 10:00 LAND MAMMALS FROM THE MIDDLE MIOCENE SHARKTOOTH HILL BONEBED, KERN GOUNTY, GALIFORNIA.

Donald R. Prothero ${ }^{1}$, Matthew R. Liter ${ }^{1}$, Lawrence G. Barnes ${ }^{2}$, and Xiaoming Wang ${ }^{2}$. ${ }^{1}$ Department of Geology, Occidental College, Los Angeles, CA 90041; ${ }^{2}$ Department of Vertebrate Paleontology, Natural History Museum of Los Angeles County, 900 Exposition Blvd., Los Angeles, CA 90007.

142 10:20 A NORTHERN OGGURRENGE OF THE COTTON RAT SIGMODON MEDIUS WITH PLIOPHENACOMYS PRIMAEVUS FROM LATE PLIOGENE AGE DEPOSITS OF MODOC GOUNTY, NORTHEASTERN GALIFORNIA.

Hugh M. Wagner. Department of Paleontology, San Diego Natural History Museum, P.O. Box 121390, San Diego, CA. 
11:00-11:20 Student Grant Awards. Titan Theatre.

11:20-12:20 Plenary Lecture. Titan Theatre.

Dr. Steve Murray, Dean of Natural Sciences and Mathematics, California State University, Fullerton.

\section{SGIENGE, POLITIGS, THE PUBLIC AND PROTEGTING CALIFORNIA'S COASTAL} MARINE ECOSYSTEMS

$12: 20-1: 20$

\section{LUNGH BREAK}

A NEW IRVINGTONIAN LAND MAMMAL ASSEMBLAGE FROM THE SAUGUS FORMATION, MOORPARK, VENTURA COUNTY, GALIFORNIA.

Hugh M. Wagner ${ }^{1}$, E. Bruce Lander ${ }^{1}$, Mark A. Roeder ${ }^{1}$, Donald R. Prothero ${ }^{2}$, and George E. McDaniel, Jr. ${ }^{3}{ }^{1}$ Paleo Environmental Associates, Inc., 2248 Winrock Ave., Altadena, CA 91001; ${ }^{2}$ Occidental College, Department of Geology, 1600 Campus Rd., Los Angeles, CA 90041; ${ }^{3}$ Anza-Borrego Desert State Park, Stout Paleontology Laboratory, P.O. Box 1720, Borrego Springs, CA 92004.

REVISED TEMPORAL RESOLUTION OF THE LATE IRVINGTONIAN AGE FAIRMEAD LANDFILL FAUNA, MADERA COUNTY, GALIFORNIA.

Hugh M. Wagner ${ }^{1}$ and L.H. Fisk ${ }^{2}$. ${ }^{1}$ Department of Paleontology, San Diego Natural History Museum, P.O. Box 121390, San Diego, CA; ${ }^{2}$ PaleoResource Consultants, 5325 Elkhorn Boulevard, \#294, Sacramento, CA 95842.

NEW RECORDS OF FOSSIL SHARKS AND BONY FISHES FROM THE LATE MIOCENE IMPERIAL GROUP OF THE ANZA BORREGO REGION, SAN DIEGO COUNTY, GALIFORNIA.

Mark A. Roeder ${ }^{1}$ and Jerry M. Hughes ${ }^{2} .{ }^{1}$ Department of Paleontology, San Diego Natural History Museum, P. O. Box 121390, San Diego, CA 92112; ${ }^{2}$ Colorado District Stout Research Center, Anza Borrego Desert State Park, 200 Palm Canyon Drive, Borrego Springs, CA 92004. MIOGENE GAPISTRANO FORMATION IN SOUTHERN ORANGE COUNTY, GALIFORNIA.

Mark R. Deering ${ }^{1}$, Lawrence A. Barnes ${ }^{2}$, Sarah A. Siren ${ }^{1,3}$, Samuel A. McLeod ${ }^{2}$, Maureen O. Walsh' ${ }^{1}$, and Karin A. Rice ${ }^{1}$. 'Stantec Consulting Inc., 19 Technology Drive, Irvine, CA 92618; ${ }^{2}$ Department of Vertebrate Paleontology, Natural History Museum of Los Angeles County, 900 Exposition Boulevard, Los Angeles, CA 90007; ${ }^{3}$ Saddleback College, 28000 Marguerite Parkway, Mission Viejo, CA 92692.

A MAMMOTH AND ASSOGIATED FAUNA FROM NEWPORT BAGKBAY 25,000 YEARS BEFORE PRESENT.

S. Gust and K. Scott. Cogstone Resource Management Inc., 1801 E. Parkcourt Place, Ste. B102, Santa Ana, CA 92701.

\section{BREAK}

VARIATION AND SEXUAL SIZE DIMORPHISM IN PLEISTOGENE GROUND SLOTHS (XENARTHRA).

Kristina R. Raymond and Donald R. Prothero. Department of Geology, Occidental College, Los Angeles, CA 90041.

\section{AT THE PAGIFIC GITY PROJECT SITE IN HUNTINGTON BEACH, SOUTHERN} GALIFORNIA.

L.H. Fisk $^{1}$ and M.R. Roeder ${ }^{2}$. ${ }^{1}$ PaleoResource Consultants, 5325 Elkhorn Boulevard, \#294, Sacramento, CA 95842; ${ }^{2}$ Paleo Environmental Associates, Inc., 1731 New Hampshire Drive, Costa Mesa, CA 92626. 
Saturday, June 2, 2007

Location: ONTIVEROS

Session: Avian Biology

Chair: Kathy Keane, Keane Biological Consulting

Saturday, June 2, 2007

150 E 9:00 NESTING SUCGESS OF GOSTA'S HUMMINGBIRD IN ARTICHOKE THISTLE INVADED GALIFORNIA GRASSLANDS.

R.J. Keber and S.A. Banack. Southern California Ecosystems Research Program, California State University, Fullerton, Department of Biological Science, Fullerton, CA 92834.

151 9:20 POPULATION STATUS AND TRENDS OF THE GALIFORNIA LEAST TERN, STERNULA ANTILLARUM BROWNI, AND THE WESTERN SNOWY PLOVER, CHARADRIUS ALEXANDRINUS NIVOSUS.

Jack M. Fancher. U.S. Fish and Wildlife Service, Carlsbad Fish and Wildlife Office, Carlsbad, CA 92011.

152 E 9:40 DISTRIBUTION AND HABITAT ANALYSIS OF THE WESTERN BURROWING OWL IN AN URBANIZING ENVIRONMENT.

Ginny A. Short. University of California, Riverside, Department of Biology, Riverside, CA 92521.

153 10:00 2006 CACTUS WREN STUDY, NATURE RESERVE OF ORANGE GOUNTY.

R.A. Hamilton and M.J. Mitrovich. Nature Reserve of Orange County, 15600 Sand Canyon Avenue, Irvine, CA 92618.

154 10:20 CHARADRIUS ALEXANDRINUS POPULATION SURVEYS AT OWENS DRY LAKE, INYO COUNTY GALIFORNIA PRE- AND POST SHALLOW FLOOD DUST GONTROL IMPLEMENTATION.

G.M. Honan ${ }^{1}$, R. Romero ${ }^{1}$, J. Gorham ${ }^{1}$, G.W. Page ${ }^{2}$, and T.D. Ruhlen ${ }^{2} .{ }^{1}$ CH2M HILL, Santa Ana, CA; ${ }^{2}$ PRBO Conservation Science, Petaluma, CA.

10:40-11:00 BREAK

11:00-11:20 Student Grant Awards. Titan Theatre.

11:20-12:20 Plenary Lecture. Titan Theatre.

Dr. Steve Murray, Dean of Natural Sciences and Mathematics, California State University, Fullerton.

SCIENCE, POLITICS, THE PUBLIC AND PROTEGTING GALIFORNIA'S COASTAL MARINE ECOSYSTEMS LUNCH BREAK

\section{Location: ONTIVEROS}

Session: Hydrology and Aquatic Life of the Santa Ana River Chair: Richard Zembal, Orange County Water District 
LEAST BELL'S VIREOS OF THE SANTA ANA RIVER - RECOVERY IN PROGRESS.

S. Hoffman, R. Zembal, J. Pike, D. Pelligrini, T. Wiater, B. Nash, M. Aimar, T. Reeser, A. Beckman, and J. Coumoutso. The Santa Ana Watershed Association, 25864-K Business Center Dr., Redlands, CA 92374.

157 2:00 RESTORATION OF THE RIPARIAN FORESTS OF THE SANTA ANA RIVER. THE SANTA ANA RIVER WATERSHED PROGRAM, 1997-2007.

Richard Zembal. Natural Resources Director, Orange County Water District, 10500 Ellis Avenue, Fountain Valley, CA 92708.

\section{HERPETOLOGICAL SURVEYS OF THE SANTA ANA WATERSHED.}

M. Aimar, R. Zembal, J. Bradley, S. Hoffman, B. Nash, T. Wiater, T. Reeser, A. Beckman, and J. Coumoutso. Santa Ana Watershed Association, 25864-K Business Center Dr., Redlands, CA 92374. ANA RIVER.

Camm C. Swift ${ }^{1}$ and Roy Leidy ${ }^{2}$. ${ }^{1}$ Entrix, Inc., 2140 Eastman Avenue, Suite 200, Ventura, CA 93003; ${ }^{2}$ EIP Associates, a division of PBS\&J, 1200 Second Street, Suite 200, Sacramento, CA 95814.

3:00-3:20 BREAK

BIOLOGIC, HISTORIC AND SOGIAL GONSIDERATIONS FOR INTRODUGTIONS OF SANTA ANA SUCKER (CATOSTOMUS SANTAANAE) AND SANTA ANA SPECKLED DAGE (RHINICHTHYS OSCULUS SSP.) INTO THE UPPER SANTA ANA RIVER.

Gar Abbas. USDA Forest Service, San Bernardino National Forest, San Bernardino, CA 92408.

FLORA OF THE SANTA ANA RIVER.

Oscar F. Clarke and Greg Ballmer.

DEMYSTIFYING A RARE AND SECRETIVE SPECIES OF THE SANTA ANA RIVER, THE SOUTH GOAST GARTERSNAKE (THAMNOPHIS SIRTALIS SSP.).

Edward L. Ervin ${ }^{1}$, Clark R. Mahrdt ${ }^{2}$, and Bonnie Nash ${ }^{3} .{ }^{1}$ Merkel \& Associates, Inc., San Diego, CA 92123; ${ }^{2}$ San Diego Natural History Museum, San Diego, CA 92101; ${ }^{3}$ Orange County Water District, Fountain Valley, CA 92708. FEDERALLY THREATENED SANTA ANA SUGKER, CATOSTOMUS SANTAANAE, IN THE SANTA ANA RIVER.

Andrew Thompson ${ }^{1}$, Jonathan Baskin ${ }^{2,}{ }^{3}$, and Tom Haglund ${ }^{2,}{ }^{3},{ }^{1}$ U.S. Fish and Wildlife Service, 6010 Hidden Valley Road, Carlsbad, CA 92011; ${ }^{2}$ Biological Sciences Department, California State Polytechnic University Pomona, 3801 West Temple Avenue, Pomona, CA $91768 ;{ }^{3}$ San Marino Environmental Associates, 560 South Greenwood Ave., San Marino, CA 91108 .

AQUATIC INSEGTS OF THE SANTA ANA RIVER: COMMUNITY STRUCTURE AND BIOASSESSMENT ON ALTITUDINAL GRADIENT.

W. E. Walton and B. A. Mullens. Department of Entomology, University of California, Riverside, CA 92521. 
Saturday, June 2, 2007

Location: ALVARADO

Session: Diseases and other Maladies of Southern California

Marine Mammals

Chair: Richard H. Evans, Pacific Marine Mammal Center

165 E 8:20 PSEUDO-NITZSCHIA BLOOM DYNAMICS IN COASTAL WATERS NEAR LOS ANGELES AND CONFIRMED CASES OF DOMOIC ACID POISONING IN MARINE MAMMALS.

A. Schnetzer $^{1}$, D.A. Caron ${ }^{1}$, L. Palmer ${ }^{2}$, M. Hunter ${ }^{3}$, and R. Evans ${ }^{3}$. ${ }^{1}$ Department of Biological Sciences, University of Southern California, Los Angeles, CA 90089; ${ }^{2}$ Marine Mammal Care Center at Fort McArthur, San Pedro, CA 90732; ${ }^{3}$ Pacific Marine Mammal Center, Laguna Beach, CA 92651.

166 8:40 DOMOIC ACID POISONING OF GALIFORNIA SEA LIONS IN SOUTHERN GALIFORNIA WATERS: GLINICAL AND PATHOLOGICAL FINDINGS.

R. H. Evans. Pacific Marine Mammal Center, 20612 Laguna Canyon Road, Laguna Beach, CA 92651.

167 9:00 LEVELS OF PGBS AND DDT IN PINNIPEDS OF THE SOUTHERN GALIFORNIA BIGHT.

Mary Blasius and G.D. Goodmanlowe. California State University, Long Beach, CA 90840.

168 9:20 A PRELIMINARY EXAMINATION OF MORTALITY PATTERNS IN STRANDED SAN DIEGO COUNTY GETACEANS, 1978-2006.

$\underline{\text { K. Danil }}^{1}$ and J. St. Leger ${ }^{2}$. ${ }^{1}$ Southwest Fisheries Science Center, 8604 La Jolla Shores Dr., La Jolla, CA 92037; ${ }^{2}$ Sea World, 500 Sea World Dr., San Diego, CA 92109.

169 9:40 STAPHYLOCOCCUS AUREUS NEPHRITIS IN A GALIFORNIA SEA LION (ZALOPHUS CANUS)

V. Favel. Pacific Marine Mammal Center, 20612 Laguna Canyon Road, Laguna Beach, $\overline{\text { CA } 92651 .}$

$170 \quad$ 10:00 BRUGELLA IN MARINE MAMMALS.

Judy St. Ledger. SeaWorld, 500 Sea World Dr., San Diego, CA 92109.

171 10:20 MISGELLANEOUS CASE REPORTS AND "SWEET TREATMENT" OF A SHARK BITE.

Lauren Palmer. Marine Mammal Care Center, Fort MacArthur, San Pedro, CA.

10:40-11:00 BREAK

11:00-11:20 Student Grant Awards. Titan Theatre.

11:20-12:20 Plenary Lecture. Titan Theatre. Dr. Steve Murray, Dean of Natural Sciences and Mathematics, California State University, Fullerton.

SGIENCE, POLITICS, THE PUBLIC AND PROTECTING GALIFORNIA'S GOASTAL MARINE ECOSYSTEMS 


\section{Saturday, June 2, 2007}

Location: GILMAN

Session: Contributed Papers

9:00 TIDAL DYNAMICS OF FECAL INDICATOR BACTERIA (FIB) IN THE BALLONA WETLANDS, LOS ANGELES COUNTY, GALIFORNIA.

A. A. Antonino ${ }^{1}$, P. M. Carter ${ }^{1}$, M. R. Ogletree ${ }^{1}$, J. H. Dorsey ${ }^{1}$ and R. Sagarin ${ }^{2} .{ }^{1}$ Loyola Marymount University, Department of Natural Science, Los Angeles, CA 90045;

${ }^{2}$ Nicholas Institute for Environmental Policy Solutions, Box 90328, Duke University, Durham, NC 27708.

173 E 9:20 PRELIMINARY ETHNOBOTANICAL INVESTIGATION ON GURRENT USE OF HYDROCOTYLE RANUNCULOIDES L.F. IN IXTLAHUCA AND SAN MATEO, TEXGALYACAC, MEXICO.

G.J. Cortez and S.A. Banack. Department of Biological Science, California State University, Fullerton, 800 N. State College Blvd., Fullerton, CA 92834.

174 M 9:40 THE USE OF BEDSIDE ULTRASOUND TO DETECT FREE FLUID IN TRAUMA PATIENTS.

Jarrod L. Larson, J. Christian Fox, Graciela Barajas, and Suleman Ahmed. University of California, Irvine Medical Center, University of California, Irvine, Department of Emergency Medicine, Orange, CA 92868.

10:00 ARMORED MIXED-SOFT SEDIMENTS - A DISTINCTIVELY DIFFERENT SEDIMENT PARADIGM?.

D. G. Lees $^{1}$ and W. B. Driskell ${ }^{2}$. ${ }^{1}$ Littoral Ecological \& Environmental Services, 1075 Urania Ave., Leucadia, CA 92024; ${ }^{2} 653620^{\text {th }}$ Ave. NE, Seattle, WA 98115.

10:20 DELAYED REGOVERY IN INTERTIDAL GLAM ASSEMBLAGES IN PRINGE WILLIAM SOUND FOLLOWING THE EXXON VALDEZ OIL SPILL CLEANUP. D. G. Lees ${ }^{1}$ and W. B. Driskell ${ }^{2}$. ${ }^{1}$ Littoral Ecological \& Environmental Services, 1075 Urania Ave., Leucadia, CA 92024; ${ }^{2} 653620^{\text {th }}$ Ave. NE, Seattle, WA 98115.

10:40-11:00 BREAK

11:00-11:20 Student Grant Awards. Titan Theatre.

11:20-12:20 Plenary Lecture. Titan Theatre.

Dr. Steve Murray, Dean of Natural Sciences and Mathematics, California State University, Fullerton.

SGIENGE, POLITICS, THE PUBLIG AND PROTEGTING GALIFORNIA'S GOASTAL MARINE ECOSYSTEMS

12:20-1:20 LUNCH BREAK

Saturday, June 2, 2007

Location: ALVARADO

Session: Contributed Papers

177 1:20 BALANCING RANIDS AND RECREATION: FOREST SERVICE EFFORTS TO PROTEGT MOUNTAIN YELLOW-LEGGED FROGS AND QUALITY REGREATION OPPORTUNITIES.

Gar Abbas, Anne Poopatanapong, and Marc Stamer. USDA Forest Service, San Bernardino National Forest, San Bernardino, CA 92408. 
$178 \mathrm{M} \quad$ 1:40 GHRONOTROPIC AND INOTROPIC EFFEGTS OF HAWTHORN (CRATAEGUS OXYCANTHA) EXTRAGTS IN GARDIOMYOCYTE-BASE ASSAY.

Satin Salehi, Shannon R. Long, Kristi M. Crofoot, and Theresa M. Filtz. Oregon State University, College of Pharmacy, Corvallis, OR.

$179 \mathrm{~F}$ 2:00 EFFECTS OF INCREASED GURRENT VELOGITY ON THE GROWTH OF JUVENILE GAPTIVE BROODSTOGK COHO SALMON (ONCORHYNCHUS KISUTCH).

John Silveus and Erick Sturm. Southwest Fisheries Science Center, National Marine Fisheries Service, 110 Shaffer Road, CA 95060.

180 2:20 ADDITIONAL RECORDS FOR PACIFIC HADAL ZONE EGHINODERMS.

K.D. Trego. Nautilus Oceanic Institute, La Jolla, CA 92037.

181 2:40 WHALE FALL DEPLETION AND ECOSYSTEM EFFEGTS FOR ABYSSAL/HADAL MEGAFAUNA ECHINODERMS

K.D. Trego. Nautilus Oceanic Institute, La Jolla, CA 92037.

3:00-3:20 BREAK

182 3:20 DYNAMICS OF PLANETARY INTERIOR OGEANS AND SURFAGE EXPANSION OF POTENTIAL ECOSYSTEMS.

K.D. Trego. Nautilus Oceanic Institute, La Jolla, CA 92037.

$183 \mathrm{~F}$ 3:40 SEASONAL AGGREGATIONS OF FEMALE ROUND STINGRAYS (UROBATIS HALLERI) IN A COASTAL ESTUARY.

G.G. Mull, K.A. Young, and C.G. Lowe. Department of Biological Sciences, California State University, Long Beach, CA 90840.

Saturday, June 2, 2007

Location: HETEBRINK

Session: Research Training Program

Chair: Dr. Martha Schwartz, Southern California Junior Academy of Sciences Committee

184 9:00 GIRGUIT DYNAMICS AND MODELING OF THE GAUSS ACGELERATOR. J. Luo and O. O. Bernal. California State University Los Angeles, Department of Physics and Astronomy, Los Angeles, CA 90032.

185 9:20 A STUDY OF ENTEROBACTERIAGEAE AT TWO ENGLOSED BEACHES IN LOS ANGELES, GALIFORNIA.

S. Yanamadala and J.H. Dorsey. Chadwick School, 26800 S. Academy Drive, Palos Verdes, CA 90274.

$1869: 40$ EXPLORATION OF PROTEIN LRP16'S FUNCTION AS A RESULT OF ITS CORRESPONDING DNA SEQUENCES THROUGHOUT THE EVOLUTIONARY TREE.

Shahla Naimi. California Academy of Math and Science, Carson, CA 90747

PERMANENT UPLIFT OF THE MENTAWAI ISLANDS AND THE MEGATRUST EARTHQAUKE GYCLE.

Hassan Ahmad. 501 N Chapel Ave. \#1, Alhambra, CA 91801.

10:20 PHYSICAL ASPECTS OF SOUTHERN GALIFORNIA BEAGHES AND HOW PEOPLE PERCEIVE THEM: CONSIDERATIONS FOR BEACH NOURISHMENT PLANNING.

Scott H. Grove. Sonora High School, La Habra, CA; California State University, Monterey Bay, CA. 
10:40-11:00

11:00-11:20

$11: 20-12: 20$

BREAK

Student Grant Awards. Titan Theatre.

Plenary Lecture. Titan Theatre. Plenary Lecture. Titan Theatre.

Dr. Steve Murray, Dean of Natural Sciences and Mathematics, California State University, Fullerton.

SCIENCE, POLITICS, THE PUBLIC AND PROTECTING GALIFORNIA'S COASTAL MARINE ECOSYSTEMS

\section{LUNCH BREAK}

PRODUCTION AND CHARACTERIZATION OF EFFICIENT C60-TETHERED AU NANOPARTICLES FOR THE DELIVERY OF PHOTOSENSITIZERS.

May Y. Chow ${ }^{1}$ and Matthias Selke ${ }^{2} .{ }^{1}$ Alhambra High School, Alhambra, CA 91801; ${ }^{2}$ California State University, Los Angeles, CA.

:40 THE SIGNAL TRANSDUGTION PATHWAY FOR MUSCLE GELL APOPTOSIS IN AGING AND INJURY.

Sanjit Datta and A.P. Sinha Hikim. Los Angeles Biomedical Research Institute at the Harbor-UCLA Medical Center, Harbor City, CA 90710.

A GASE-CONTROL STUDY OF COMMUNITY-ACQUIRED METHICILLIN RESISTANT STAPHYLOCCUS AUREUS SKIN AND SOFT TISSUE INFECTIONS AMONG INMATES IN THE LOS ANGELES COUNTY JAIL.

Ji-Mi (Jenny) Lee. California Academy of Mathematics and Science (CAMS), Carson, CA 90747; California State University, Dominguez Hills, 100 East Victoria Street, Carson, CA 90747.

THE ABILITY OF BACCHARIS SALICIFOLIA TO ABSORB CADMIUM AS AN EFFLUENT: IMPLICATIONS FOR PHYTOREMEDIATION: YEAR TWO.

Nisha Wadhwa ${ }^{1}$ and Katie Brandt ${ }^{2} .{ }^{1}$ Palos Verdes Peninsula High School, Rolling Hills Estates, CA; ${ }^{2}$ California State University, Dominguez Hills, CA.

PROTEASE INHIBITORS IN AUGMENT TEMOZOLOMIDE-BASED TREATMENT FOR MALIGANT GLIOMAS

J.J. Wang, W.J. Wang, and T.C. Chen. Department of Neurosurgery, University of Southern California, Los Angeles, CA 90033.

BREAK

OXIDATION OF L-DOPA IN MUSSEL BYSSUS DISC ADHESION

Renee Bogdanovic. Palos Verdes Peninsula High School, Rolling Hills Estates, CA 90274.

STUDY ON THE TRUNGATION OF GONVEX SYMMETRICAL POLYHEDRA

Brian Li. Chadwick School, $26800 \mathrm{~S}$. Academy Drive, Palos Verdes, CA.

PREDICTING LUNG GANCER RELAPSE USING LEVELS OF 2881 PROTEINS.

Timothy $\mathbf{W u}^{1}$ and Dennis Kibler ${ }^{2} .{ }^{1}$ University High School, 4771 Campus Drive, Irvine, CA 92612; ${ }^{2}$ University of California, Irvine, CA 92697.

PROTOCOLS FOR HALIOTIS RUFESCENS EGG CRYOPRESERVATION AND IN VITRO FERTILIZATION (YEAR 2).

Julie A. Guerin. Cabrillo Marine Aquarium, San Pedro, CA 90731; Palos Verdes Peninsula High School, Rolling Hills Estates, CA 90274.

4:40 MAGNETORHEOLOGICAL FLUID SHEER STRESS AND THE MORPHING OF AIRPLANE WINGS.

Anshu Vaish. Palos Verdes Peninsula High School, Rolling Hills Estates, CA 90274. 


\section{$2 \mathrm{BHL}$ Biodiversity Heritage Library}

2007. "Southern California Academy of Sciences 2007 Session Schedule." Bulletin 106(2), 62-84.

https://doi.org/10.3160/0038-3872(2007)106[62:scaoss]2.0.co:2.

View This Item Online: https://www.biodiversitylibrary.org/item/123214

DOI: https://doi.org/10.3160/0038-3872(2007)106[62:scaoss]2.0.co;2

Permalink: https://www.biodiversitylibrary.org/partpdf/292020

\section{Holding Institution}

California Academy of Sciences

\section{Sponsored by}

California Academy of Sciences Library

\section{Copyright \& Reuse}

Copyright Status: In copyright. Digitized with the permission of the rights holder.

This document was created from content at the Biodiversity Heritage Library, the world's largest open access digital library for biodiversity literature and archives. Visit BHL at https://www.biodiversitylibrary.org. 